\section{NEW RECORDS OF LASIOPTERINE MIDGE GALLS (DIPTERA: CECIDOMYIIDAE: CECIDOMYIINAE: LASIOPTERIDI) FROM MAHARASHTRA}

\section{R.M.Sharma}

Zoological Survey of India, Western Regional Station, Vidyanagar, Sector 29, PCNT post office, Akurdi, Pune, Maharashtra 411044, India.

Galls or plant tumours are structural abnormalities, which arise mostly by overgrowth (hypertrophy) and excessive cell division of tissues (hyperplasy) in response to the feeding activity of a parasite on the host plant. Among gall making insects, cecidomyiids or gall midges as they are popularly called, are well known on a variety of plants.

During the course of faunistic studies of gall inducing insects from Maharashtra State, I collected a large number of galls caused by midges. Of these, four different species of Lasiopterine midges caused galls on three different plant species of family Cucurbitaceae and one Leeaceae. A perusal of the monumental works on plant galls of India (Mani, 1973, 2000) revealed that these are not yet reported from Maharashtra and thus, constitute the first record from the State. Details of galls formed by Lasiopterine midges on various host plants are discussed below.

\section{Diplocyclos (=Bryonia) palmatus (L.) Jeffrey (Family: Cucurbitaceae) \\ Gall caused by Lasioptera bryoniae Schiner}

Stem- gall. Elongate- fusiform, fleshy, solid, tomentose swelling of tender branches; indehiscent, with axial larval cavities in the middle; gall measures about 25-30mm long and $15-20 \mathrm{~mm}$ thick. This gall is practically similar to the gall number 218 of Mani (1973). A large number of midges were bred from these galls together with Stenobracon sp., a braconid parasite. The host plant has ethnobotanical significance as the tribals use its seeds against snakebites and for the treatment of female infertility. In vernacular language the plant is known as 'Shivlingi'.

Distribution: Amravati District, Melghat Project Tiger, viii.1993; Akurdi, Pune District, Maharashtra, viii-ix, 2000, Coll. R.M. Sharma.
Luffa acutangula Roxb.

(Family: Cucurbitaceae)

Common name: Ridged Gourd

Gall caused by Lasioptera nenuae (Grover)

Stem-gall, elongate, fusiform or ovoid, sometimes irregular, solid, smooth or obscurely costate, fleshy, yellowish-green, indehiscent, persistent tumescence of tender branches. Larval chambers elongate axially. Length of gall varies from $25-50 \mathrm{~mm}$ long and $10-15 \mathrm{~mm}$ thick. A fruit fly (Tephritidae) breeds in the flesh of this gall.

Distribution: Amravati District, Melghat Project Tiger, Maharashtra; Rajasthan and western Uttar Pradesh, viii.1993, Coll. R.M. Sharma.

\section{Momordica dioica Roxb. (Family: Cucurbitaceae)}

Common name: Bristle Gourd

Gall caused by Lasioptera sp.

Stem-gall, fusiform, elongate, solid, indehiscent, fleshy, costate, light yellowish-green swelling of tender branches. Larval cavities axial. Length of the gall varies from $25-30 \mathrm{~mm}$ and thickness from $10-15 \mathrm{~mm}$.

Distribution: Coromandel Coast; Maharashtra; Sanjay Gandhi National Park, Borivali, Maharashtra, ix. 2001, Coll. R.M. Sharma.

\section{Leea sp.}

(Family: Leeaceae)

Gall caused by Lasioptera sp.

Leaf-gall, epi-hypophyllous, pyriform, conical or subglobose, sessile, solid, hard, unilocular pouch-galls. Each gall chamber harbours single orange coloured larva. This gall is similar to gall number 583 of Mani (1973). A large number of female midges along with braconid parasites were reared from these galls.

Distribution: Travancore (Kerala); Tamhini, Mulshi, Pune District, Maharashtra, vi.1996, Coll. R.M. Sharma.

\section{Acknowledgements}

I am thankful to Dr. J.R.B. Alfred, Director, Zoological Survey of India, Kolkata and Dr. M.S. Pradhan, Scientist-D \& Officer-incharge, Zoological Survey of India, Pune for facilities.

\section{References}

Mani, M.S. (1973). Plant Galls of India. Macmillan India, 354pp. Mani, M.S. (2000). Plant Galls of India. $2^{\text {nd }}$ edition. Science Publishers, Enfield, USA, 477pp. 